\title{
Buccini, Stefania.
}

\section{Francesco Pona. L'ozio lecito della scrittura.}

Biblioteca dell'Archivium romanicum. Series 1: Storia, Letteratura, Paleografia 395. Florence: Leo S. Olschki, 2013. Pp. xiv, 225. ISBN 978-88-222-6130-4 (paperback) €24.

Many years after Giorgio Fulco published the critical edition of La Lucerna (1973), Buccini's book draws attention to the opera omnia written by Francesco Pona (1595-1655), nobleman and doctor in the Verona of the sixteen hundreds. Buccini's publication is divided into four main chapters that try to make sense of Pona's extended production, and to contextualize the author's complex, intellectual biography. By presenting significant sources-texts well known or, in some cases, as yet unpublished-the reader can follow the education of the young student in Padua and Bologna until the last years of his career, when he utterly denied libertine themes debated in La Lucerna, first published in 1625 .

Chapter 1, "L'esordio" (Debut), describes Pona's poetical debut in 1617 with his Rime (poems), published again two years later in a longer version. This is the period when the author began to get in touch with different academies, such as the Accademia dei Gelati in Bologna, the Accademia dei Filarmonici in his hometown, and, later, the Accademia degli Incogniti in Venice. His translation of Ovid's Metamorphoses, in 1618, achieved success among both scholars and general readers. In 1620, "Il Sileno" was published, a fictional dialogue between a foreigner from Bologna, a citizen of Verona, and a servant-who discourse on the beauty and amenities located in the garden of Count Giusti, to whom the work is dedicated. "Il Paradiso de' Fiori" followed two years later in 1622, a text that explores nature and the arts by making an inventory of features related to gardens, wild fields, and decorative and medicinal plants.

The following chapter, "La trasgressione" (Transgression), is mostly dedicated to Pona's major work. It was in 1625 that La Lucerna di Eureta Misoscolo came to life, a work considered by some to be the first modern novel. Its sources and models must be sought among both seventeenth-century authors, such as Nicolò Franco, and classical ones, such as Lucano. Its motif is the reincarnation of a soul throughout forty-seven different bodies, human and not, until reaching the ultimate stage of a lucerna, an oil-lamp. The innovative plot develops in 
a dialogue between the lamp and a student in Padova (the Eureta of the title) unfolding in four nights; the lamp is the teller of its adventurous life and the eventful process of reincarnation, a practice that allows the soul to experience the multifaceted world.

Buccini addresses issues with regard to the year of publication, apparently delayed compared with the early composition of the text. Connections to the Venetian environment and specifically with the Incogniti, the libertine academy, were crucial to Pona's literary production. In this same period, Pona produced "La Maschera Iatrapolitica," a fictitious battle between the Heart and the Brain, shortly followed by a translation of John Barclay's "Argenis."

It is in the third chapter, "Il conformismo" (Conformity), that we read about the profound crisis of Pona and his consequent self-censorship, which leads the author to the composition of Il Parthenio (1627), a moral comedy in four acts displaying the triumph of virginity. (The two main charactersPartenio and Virginità-get married, and eventually the latter guides her spouse to Paradise.) After the composition of Sonetti berneschi (1627) - a series of commending poems dedicated to Count della Torre-Pona wrote Il Christo Passo, a sacred play, published in 1629. It is a five-act drama in prose that exposes the prominent moments of Christ's passion; notably, it was not meant to be performed on stage.

The year 1630 saw the great plague that affected the population of many towns in Italy. Buccini records two pamphlets about the contagion- "Del modo di preservarsi dalle malattie pestilenti" and "La Remora" - both published in 1630. It was 1631 when Pona wrote his main historical work, "Il Gran Contagio di Verona," an essay that granted him the honour of being part of the Collegio dei Medici, the most important organization of doctors in Verona at that time.

Another masterpiece written in 1632 is the renowned "Galeria delle Donne celebri," a prose essay on the vices and virtues of the fair sex, with examples such as Mary Magdalene and Elizabeth of Ungary. La Messilina, a short novel, was meant to be its counterpart.

The final chapter, entitled "L'epilogo" (Epilogue), focuses its attention on the so-called inchiostri votivi (votive compositions) during the years 1645-55, the last ten years of Pona's literary activity. Having rejected the first main work of his youth, La Lucerna, the author dedicates himself to composing moral works of religious inspiration and biographies of saints. 
The volume ends with illustrated reproductions of colophons from Pona's debated works, and an extended bibliography.

SEBASTIANO BAZZICHETTO

University of Toronto

\section{Bucer, Martin.}

De vera et falsa caenae dominicae administratione (1546). Ed. Nicholas Thompson.

Studies in Medieval and Reformation Traditions 184. Leiden: Brill, 2014. Pp. xiv, 320. ISBN 978-9-0042-7323-8 (hardcover) €126/\$163.

This is a book for Bucer scholars; a high level of familiarity with his works and doctrine is assumed and necessary. Having said that, Thompson's introductory material does add sharper definition to the context in which De vera et falsa was written-and this is interesting, even if the treatise itself adds little to our understanding of Bucer's theology as a whole. Bucer was known as a compromiser; he advanced formulae aimed at reconciling first Luther and Zwingli and subsequently Protestants and Catholics, and was therefore somewhat distrusted by all sides and often pilloried for his efforts. Nonetheless he wrote treaties and letters to all interested parties, clear in the belief that neither side in any dispute could be allowed an absolute victory. De vera et falsa, little regarded at the time, falls into this diplomatic-theologic effort.

Thompson also provides a pithy biography of Bartholomaeus Latomus who was Bucer's main opponent at the Regensberg assemblies and a target of the treatise. Like Bucer, Latomus disliked the obscurantism of the scholastics and the hide-bound doctrinaire traditionalists alike; he was no evangelical, however, aligning instead with the Catholic reformers of the Pole or Contarini camp. If Bucer could have swayed Latomus to support more clear-cut reform, other moderates (he believed) may have followed suit-but sola scriptura and the council of Trent became obstacles to any agreement. Latomus was far more willing to subscribe to channels of traditional reform and authority-the pope, the emperor and the general council-so he took a wait-and-see stance, whereas Bucer hoped and held out for a comprehensive Germany-based council with equal evangelical participation. At the centre of their dispute were three 